\title{
China's Natural Wetlands: Past Problems, Current Status, and Future Challenges
}

Natural wetlands, occupying $3.8 \%$ of China's land and providing $54.9 \%$ of ecosystem services, are unevenly distributed among eight wetland regions. Natural wetlands in China suffered great loss and degradation (e.g., $23.0 \%$ freshwater swamps, $51.2 \%$ costal wetlands) because of the wetland reclamation during China's long history of civilization, and the population pressure and the misguided policies over the last 50 years. Recently, with an improved understanding that healthy wetland ecosystems play a vital role in her sustainable economic development, China started major efforts in wetland conservation, as signified by the policy to return reclaimed croplands to wetlands, the funding of billions of dollars to restore degraded wetlands, and the national plan to place $90 \%$ of natural wetlands under protection by 2030. This paper describes the current status of the natural wetlands in China, reviews past problems, and discusses current efforts and future challenges in protecting China's natural wetlands.

\section{INTRODUCTION}

Healthy natural wetland ecosystems play a vital role in sustainable development of China, which has been recognized by the Chinese government $(1,2)$. Natural wetlands occupy $3.8 \%$ of China's terrestrial area (1), with the total wetlands areas estimated at $8.0 \%$ (compared with $6.0 \%$ in the world). Natural wetlands in China provide $54.9 \%$ of the annual ecosystem services for the country $(3,4)$. In addition, $54 \%$ of endangered species of ducks and geese in Asia have been recorded in China's wetlands $(2,5)$. Despite their importance as natural resources and as natural regulators to environmental problems $(3,4)$; however, natural wetlands in China suffered great losses and degradation, not only because of wetland reclamation during the country's long history of civilization but also because of the severe population pressure and the misguided policies over the last 50 years $(1,5)$. In this paper, we will describe the current status of the natural wetlands in China, review past problems (especially over the last 50 years), summarize current efforts, and discuss future challenges in protecting China's natural wetlands. Our goal is to provide a synthesis and the basic information about the natural wetlands in China so that people from institutions of scientific research and organizations of conservation abroad can learn and join in our efforts of wetland protection and help us develop effective conservation strategies for the science-based decision making by the government. It should be pointed out that the Chinese government uses a broader definition of wetlands than the Ramsar Convention (6) in that deep lakes and large rivers are regarded as wetlands.

\section{CURRENT STATUS OF NATURAL WETLANDS IN CHINA}

\section{Natural Geography}

China is a large country ( 9.6 million $\left.\mathrm{km}^{2}\right)$, with diverse geomorphology $(7,8)$. Her vast territory is marked by many unique geomorphological features: the Qinghai-Tibet Plateau in her southwest ( 2.5 million $\mathrm{km}^{2}$; the highest and largest plateau, known as the "roof of the world"), the Tarim basin in her west ( 0.4 million $\mathrm{km}^{2}$; the largest basin in the world), the Gobi desert in her north (1.3 million $\mathrm{km}^{2}$; one of the largest hot deserts in the world), and the Huang $\mathrm{Tu}$ plateau in the midwest $(0.3$ million $\mathrm{km}^{2}$; the largest loess plateau in the world) (Fig. 1) (7, 8 ). The aquatic system of China is composed of many rivers and lakes, and a long coastline $(18000 \mathrm{~km})$ in the east and southeast, including the four largest rivers (and their associated lakes), i.e., the Yangtze River (Change Jiang) in central China (6300 km; the third longest in the world), the Yellow River (Huang He) in the northern China plains (5464 km; "the cradle of the Chinese civilization"), the Songhua River in the northeastern plain $(2308 \mathrm{~km})$, and the Pearl River (Zhu Jiang) in the south $(2214 \mathrm{~km})$ (Fig. 1) $(7,8)$. In general, the western part of China is dominated by highlands, mountains, and deserts, whereas the eastern part of China contains almost all low-lying areas and supports dense populations and industrial and agricultural bases of the country.

\section{Main Types and Distribution Patterns}

China has all of the 26 natural and 9 human-made wetland types delineated in the Ramsar Convention $(1,9)$. The natural wetlands in China are unevenly distributed among eight wetland regions $(9,10): i)$ the northeast region dominated by freshwater swamps; $i i)$ the northwest region by saline lakes and swamps in dry climate; iii) the southwest plateau region by subalpine lakes; iv) the south and southeast region by rivers; v) the coastal region by tidal swamps, salt marshes, and mud-lands; vi) the middle-lower Yangtze River region by lake groups and river systems; vii) the middle-lower Yellow River region by lake groups and river systems; and viii) the Tibet plateau region by alpine lakes and swamp groups (Fig. 1). Freshwater swamp is the largest wetland type in area, most of which is located in northeastern China $\left(68000 \mathrm{~km}^{2}\right.$; dominated by species of Carex, Phragmites, Juncus, Scirpus, Acorus, Cyperus) and the Tibetan Plateau (55 $000 \mathrm{~km}^{2}$; dominated by species of Kobresia, Carex, Pedicularis, Phragmites, Blymus, Cyperus). Note that the Tibetan Plateau possesses specific wetland types where the average elevation is more than $3000 \mathrm{~m}$. The top five largest freshwater lakes of China (10 $800 \mathrm{~km}^{2}$; dominated by species of Potamogeton, Prgamites, Acorus, Juncus, Ranalisma, Brasenia, Miscanthus, Vallisneria, Cyperus) are all distributed in the middle and lower tributaries of the Yangtze River (e.g., Poyang Lake, Dongting Lake), and many saline lakes exist in the Tibetan Plateau and northwestern China. The tidal wetlands (21 $000 \mathrm{~km}^{2}$; dominated by species of Phragmites, Scirpus, Spartina, Imperata, Typha, Suaeda, and Zoysia; with additional $850 \mathrm{~km}^{2}$ of mangrove) are found along the coast, especially near the estuaries of big rivers (11).

\section{Ecosystem Services}

China's natural wetlands, occupying only $3.8 \%$ of the land, provide a significant amount of ecosystem services, including 
Figure 1. Distribution patterns of natural wetlands in the mainland of China. The natural wetlands in China are grouped into eight regions: the northeast region dominated by freshwater swamps, the northwest region by saline lakes and swamps in dry climate, the southwest plateau region by subalpine lakes, the south and southeast region by rivers, the coastal region by tidal swamps, salt marshes, and mud-lands, the Tibet plateau region by alpine lakes and swamp groups, and the regions along the middle-lower sections of the Yangtze and Yellow rivers by lake groups and river systems.

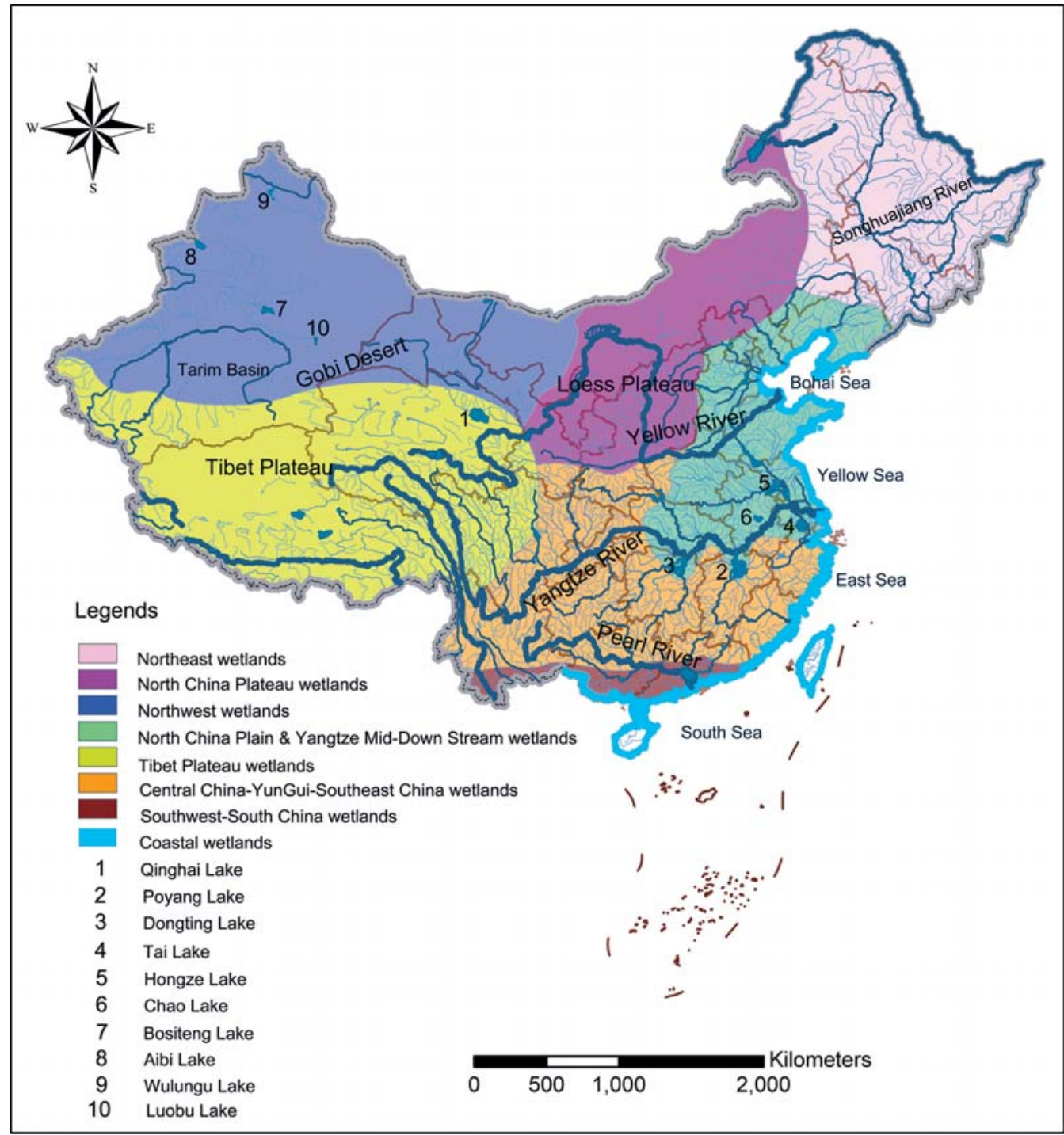

freshwater supply, flood regulation, wastewater storage and natural purification, wildlife habitat, and aquatic life preserve $(3,4)$. Based on the suggested values of all the major ecosystem types $(3,4)$, the total value of natural wetlands could account for $54.9 \%$ of the estimated 903 thousand million dollars (USD) of annual ecosystem services in China (3). For example, the freshwater resources in China are estimated at $2800 \mathrm{~km}^{3}$, of which $82.1 \%$ is contained in wetlands (i.e., swamps, rivers, lakes) and $17.9 \%$ in 85000 reservoirs (12). Based on previous studies $(10,13-16)$ and our own calculations, wetlands provide pollution control by removing 4.6 trillion gram $(\mathrm{Tg})$ of total nitrogen (TN) and $0.6 \mathrm{Tg}$ of total phosphorus (TP) from water resources in China, and carbon (C) storage of 0.35 quintillion gram (Eg) (mostly in $13000 \mathrm{~km}^{2}$ of the peat lands). In addition, China's natural wetlands are important to migratory bird conservation, providing habitats for $60 \%$ of the species of cranes (e.g., Grus, Anthropoides, Rallus, Crex, Porzana, Otis) and 26\% of the species of geese and ducks (e.g., Anser, Branta, Cygnus, Tadorna, Anas, Netta, Aythya, Aix, Mergus) of the world (2, 17). In particular, more than $90 \%$ of individuals of white crane (Grus leucogeranus), red-crown crane (Grus japonensis), and swans (Cygnus cygnus and Cygnus olor) winter in the coastal wetlands and lakes in China $(2,18)$.

\section{Current Threats}

China's natural wetlands are under great threats from reclamation, water diversion and dam construction, pollution, resource overuse, biological invasion, and desertification and climate change. The government has recognized 323 natural wetland areas in China as being of national importance $(1,2)$. These natural wetland areas of national importance account for $39.6 \%$ of the total area of natural wetlands, including 149 lakes (with a total area of $42800 \mathrm{~km}^{2}$ ), 92 swamps $\left(73500 \mathrm{~km}^{2}\right.$ ), 60 costal wetlands $\left(21000 \mathrm{~km}^{2}\right)$, and 22 rivers $\left(5300 \mathrm{~km}^{2}\right)$. Among them, however, about 60 lakes, 18 swamps, and 15 coastal wetlands are still in great danger to reclamation, water pollution, and overharvest of fisheries, whereas about 89 lakes and 26 swamps are being threatened by excessive water diversion and 64 lakes by sedimentation $(1,18,19)$. These and other emergent threats (e.g., biological invasion, global climate change) must be eliminated or minimized to preserve the natural wetlands in China.

\section{PAST PROBLEMS OF NATURAL WETLANDS IN CHINA}

\section{Loss of Wetlands and Their Ecological Services}

Unfortunately, China's natural wetlands suffered tremendous loss over the past 50 years. In terms of the total area, the country lost $23.0 \%$ of freshwater swamps, $16.1 \%$ of lakes, $15.3 \%$ of rivers, and $51.2 \%$ of costal wetlands (Table 1). Such large-scale wetland destruction may have caused an estimated annual loss of ecosystem services by 1.57 thousand million dollars (USD) (Table 1). For example, the lost areas of swamps, lakes, and 
Table 1. The losses of the natural wetlands and the associated ecosystem services in China over the last 50 years.

\begin{tabular}{|c|c|c|c|c|c|c|}
\hline Wetland Type & $\begin{array}{c}\text { Area in } 1950 \\
\left(10^{3} \mathrm{~km}^{2}\right)\end{array}$ & $\begin{array}{c}\text { Area in } 2000 \\
\left(10^{3} \mathrm{~km}^{2}\right)\end{array}$ & $\begin{array}{l}\text { Area loss } \\
\left(10^{3} \mathrm{~km}^{2}\right)\end{array}$ & $\begin{array}{c}\text { Area loss } \\
(\%)\end{array}$ & $\begin{array}{l}\text { Ecosystem services } \\
\left(10^{3} \text { USD }^{-2} \mathrm{ym}^{-1}\right)\end{array}$ & $\begin{array}{l}\text { Value loss } \\
\left(10^{9} \text { USD }^{-1}\right)\end{array}$ \\
\hline Freshwater swamps & 178 & 137 & 41 & 23.0 & 1958.0 & 80.3 \\
\hline Lakes & 143 & 120 & 23 & 16.1 & 849.8 & 19.6 \\
\hline Rivers & 95 & 82 & 13 & 15.3 & 849.8 & 11.1 \\
\hline Coastal wetlands & 43 & 21 & 22 & 51.2 & 2091.8 & 46.0 \\
\hline Total & 459 & 360 & 99 & 21.6 & - & 157.0 \\
\hline
\end{tabular}

The data for wetland area in 2000 came from the first national wetland inventory (1) and those in 1950 were reconstructed by the authors based on the refs. $1,5,9,11,14,15,17,18,19,26,28$, 29, 31-35, and 46. The average estimates of ecosystem services in US dollars were cited from references 3 and 4 , and the value loss was calculated as the product of the lost area and the average ecosystem service value. The freshwater swamps include typical swamps, wet meadows, and saline marshes of northwestern regions; the lakes include open water area at mean water level and the lacustrine swamps; the rivers include river courses and riverine swamps; and the coastal wetlands only include tidal swamps, salt marshes, and mud-lands. The shallow sea wetland was excluded from the coastal wetlands in this table because the data are questionable. The inventory data contain only those that are more than $1 \mathrm{~km}^{2}$ in area for wetlands and $10 \mathrm{~m}$ in width for rivers.

rivers may have amounted to a reduction of water storage capacity by $237 \mathrm{~km}^{3}$ (i.e., $8.5 \%$ of their total storage capacity) $(12$, $19,20)$, whereas during the same time, the construction of 85000 or so reservoirs increased water storage only by $36 \mathrm{~km}^{3}$. In addition, the five largest lakes in the middle and lower tributaries of the Yangtze River alone lost $44 \mathrm{~km}^{3}$ of their volumes and resulted in increased flooding frequency from once every 50 years to once every 10 years (18). Given that, on average, swamps (including lacustrine and riverine wetlands) can remove $\mathrm{TN}$ by $29.8 \mathrm{~g} \mathrm{~m}^{-2} \mathrm{y}^{-1}$ and TP by $3.8 \mathrm{~g} \mathrm{~m}^{-2} \mathrm{y}^{-1}$ and costal wetlands (including tidal swamp, salt marsh, and mud-land) remove TN and TP by 25.0 and $5.0 \mathrm{~g} \mathrm{~m}^{-2} \mathrm{y}^{-1}$, respectively $(10,13,14)$, the loss of these wetlands may have led to an annual reduction of water purification capacity by $2.8 \mathrm{Tg} \mathrm{TN}$ and $0.4 \mathrm{Tg} \mathrm{TP}$ in China. These lost water purification capacities amounted to $151.4 \%$ of TN and $64.0 \%$ of TP discharged in 2000 from the industrial and domestic activities in China (21). The loss of wetlands also resulted in extinction of many species that required wetlands as their vital habitats (Table 2). Among the known animal species that became extinct over the past 100 years or so, most of them were wetlands species (Table 2), including Xinjiang big-head fish (Aspiorhynchus laticeps), estuary crocodile (Crocodilus porosus), phoenix-head sheldrake (Tadorna cristata), and wild David deer (Elaphurus davidianus). Most of the extinctions were because of the loss of habitats caused by wetlands destruction (22). Another extraordinary loss of wetlands species was the wild rice (Oryza meyeriana), which was discovered in the swamps of the Hainan Island of Southern China in 1970s and was used to create a hybrid rice; this new crop increased the rice production by 3.0 quadrillion gram $(\mathrm{Pg})$ in China (23), but wild rice populations disappeared from its natural environments $(10,23)$.
In addition to direct destruction of wetlands, there were other problems associated with wetland health and conservation, such as water pollution, $\mathrm{C}$ storage loss, and biological invasion. These problems were just as severe as the wetland loss in China.

\section{Water Pollution}

Water pollution, from both point and nonpoint sources, presents serious problems that not only damage wetlands and other natural resources but also threaten public health and livelihood. One doggerel by local people vividly depicts the dynamics of water pollution in Eastern China over the last 50 years: "Cleaning rice and vegetable in the 1950s; washing cloth in the 1960s; becoming dirty in the 1970s; disappearing of fish and shrimp in the 1980s; causing bodily injury in the 1990s." In the early 1970s, water quality began to show effects of increased discharge of wastewater from industrial and domestic activities and runoffs from nonpoint sources, such as fertilizers used in agriculture. Over the period of 1980-2000, the wastewater discharge increased by $180 \%$ from industry and $380 \%$ from residential sources (24), and much of the wastewater was poorly treated or untreated and full of pollutants (21). During 1950 2000 , the annual consumption of fertilizers in China increased by 530 times, whereas the area of aquatic culture increased by 6.3 times and its production by 125 times (Fig. 2) (25). Much of the fertilizers $(50 \%-70 \%)$ ended up in the natural wetlands either by direct discharge or by accumulation of runoffs $(21,25)$. Excessive nutrient loading and poorly treated wastewater discharge greatly affected water quality of rivers and lakes. Among the 1200 monitored rivers, $70.8 \%$ was polluted and

Table 2. The numbers of species that live or are extinct in natural wetlands of China.

\begin{tabular}{|c|c|c|c|c|c|c|}
\hline \multirow[b]{2}{*}{ Taxon } & \multicolumn{3}{|c|}{ No. species } & \multicolumn{3}{|c|}{ Species lost or endangered } \\
\hline & Wetland & China & Percentage & Wetland & China & Percentage \\
\hline \multicolumn{7}{|l|}{ Plants } \\
\hline Moss & 270 & 2200 & 12.3 & 15 & 40 & 37.5 \\
\hline Fern & 70 & 2400 & 2.9 & 25 & 110 & 22.7 \\
\hline Gymnosperm & 20 & 250 & 8.0 & 5 & 65 & 7.7 \\
\hline Angiosperm & 1200 & 30000 & 4.0 & 75 & 1000 & 7.5 \\
\hline Subtotal & 1560 & 34850 & 4.5 & 120 & 1215 & 9.9 \\
\hline \multicolumn{7}{|l|}{ Animals } \\
\hline Mammal & 30 & 580 & 5.2 & 60 & 135 & 44.4 \\
\hline Bird & 270 & 1250 & 21.6 & 85 & 180 & 47.2 \\
\hline Reptilian & 120 & 380 & 31.6 & 15 & 20 & 75.0 \\
\hline Amphibian & 280 & 280 & 100.0 & 10 & 10 & 100.0 \\
\hline Fish & 1040 & 3860 & 26.9 & 170 & 200 & 85.0 \\
\hline Subtotal & 1740 & 6350 & 27.4 & 340 & 545 & 62.4 \\
\hline Total & 3300 & 41200 & 8.0 & 460 & 1760 & 26.1 \\
\hline
\end{tabular}

The species data for wetlands were based on the first national wetland inventory from 1996 to $2003(2,5)$, with minor corrections made based on recent publications $(9-11,15,17,18)$. The species data for China come from "National Report of Biodiversity of China" (1998) (22). 


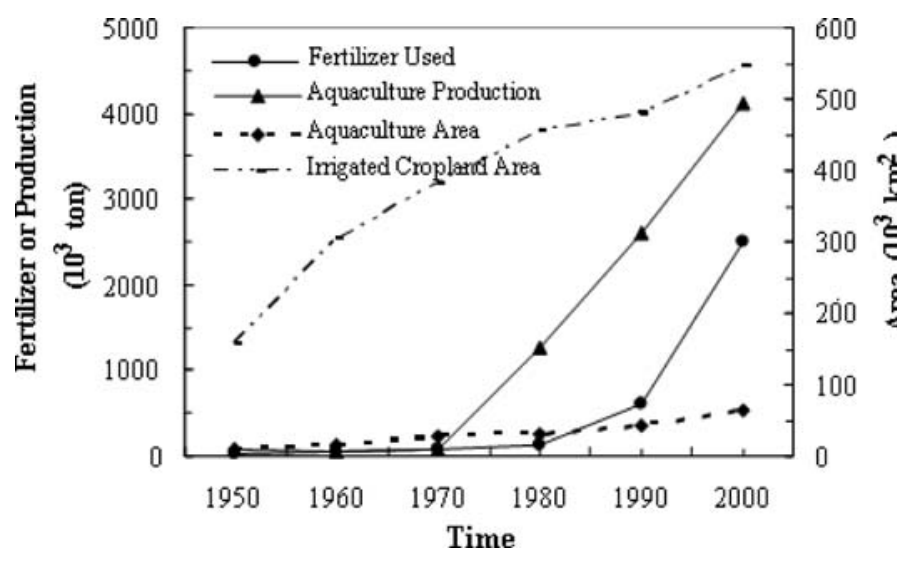

Figure 2. The changes in agricultural activities during the last 50 years in China. The data for irrigated cropland area and fertilizer use came mainly from refs. 25 and 35 , with the modifications of the data before 1970 by the information in refs. 12 and 40 . The data for aquatic culture and production were obtained mainly from refs. 40 and 41, with minor corrections based on refs. 12, 35, 42 and 43.

63.1\% were severely polluted (5). Fishes and shrimps disappeared from $33 \%$ of the total length of these rivers. The Huaihe, Haihe, and Liaohe in temperate China were among the most polluted rivers (14). It was reported in 2000 that $75 \%$ of lakes were eutrophic and that $20 \%$ of these lakes lost their basic ecosystem functions, especially those nearby the cities with rapid economic development (5). The Chaohu, Taihu, and Tianchi lakes were severely polluted, and their ecosystem structure was almost collapsed (18). The gloomy picture of the polluted wetlands can be translated into an alarming crisis of public health, because of the limited freshwater resources in China. China has $2800 \mathrm{~km}^{3}$ freshwater resources (i.e., about $2206 \mathrm{~m}^{3}$ per person) $(5,12)$. However, because of water pollution, only $40 \%-50 \%$ of the freshwater resources can be used directly for human consumption $(12,20)$, which makes China one of the lowest per capita freshwater use in the world (below the United Nations level of water stress at $1700 \mathrm{~m}^{3}$ or less per person annually) $(2,12,20)$. How to effectively use the freshwater resources (e.g., by increasing wetland areas and, thus, storage, or by cleaning up the polluted waters) will remain a daunting challenge for China in the years to come.

\section{Loss of Carbon Storage}

Wetlands, especially peat lands, are major carbon (C) sinks among different ecosystem types $(3,4)$. There are $13000 \mathrm{~km}^{2}$ of peat lands in China, most of which are distributed in the Tibetan Plateau (79\%) and the northeastern China (21\%) (9). Most of peat lands are dominated by grass and sedge species, and have a mean $\mathrm{C}$ content of $28.2 \%$ in weight (15). The rate of peat accumulation is $0.48 \mathrm{~mm} \mathrm{y}^{-1}$ in the Tibetan Plateau and $0.40 \mathrm{~mm} \mathrm{y}^{-1}$ in northeast China (26). Peat mining for uses as fertilizers and cement additives was the primary cause of peat land destruction in China. With 5.0 Tg of peat mined annually and $4500 \mathrm{~km}^{2}$ of peat land destroyed during the last 50 years (15), peat mining resulted in a $\mathrm{C}$ release of $1.48 \mathrm{Tg}^{-1}$. In addition, large areas of the swamps, including $75.6 \%$ of swamps in the northeastern China, were converted to croplands (Fig. 3). The (nonpeat) swamps are mainly dominated by Phragmites, Acroras, and Carex, and have high organic carbon content in the soil because of their low decomposition rate. For these swamps, the $\mathrm{C}$ content is $1.5 \%$ on average (with a range of $0.3 \%-5.0 \%$ ), and the mean bulk weight is $1.22 \mathrm{~g} \mathrm{~cm}^{-3}$ (with a range of $0.28-1.44 \mathrm{~g} \mathrm{~cm}^{-3}$ in the top $25 \mathrm{~cm}$ of soil) $(15,16,26)$. The conversion of the swamps to croplands alone led to the $\mathrm{C}$ storage loss of $4.58 \mathrm{Tg} \mathrm{y}^{-1}$. The total loss of $\mathrm{C}$ storage $(6.06 \mathrm{Tg}$

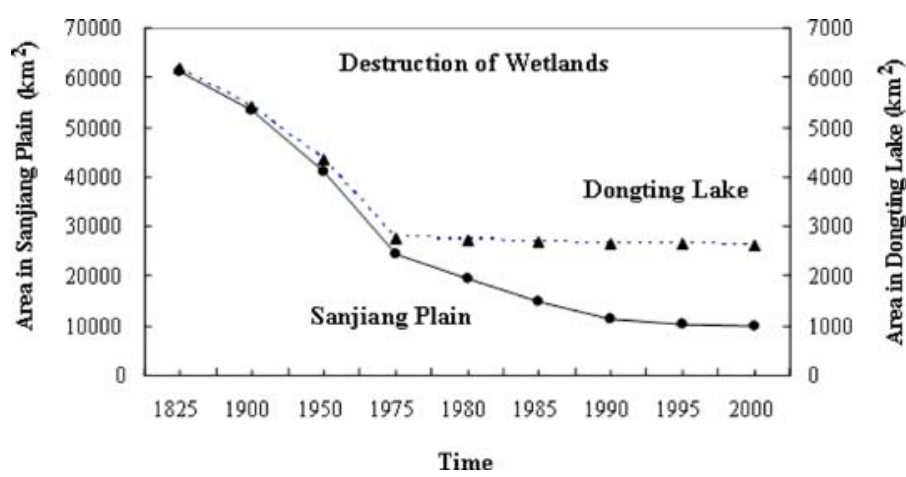

Figure 3. Wetland destruction in the Sanjiang Plain and Dongting Lake. The Sanjiang Plain swamps used to be the largest freshwater swamps in China, whereas Dongting Lake used to be the largest lake in China; but both of them became the second largest because of large-scale reclamation. The data for the Sanjiang Plain swamps came from refs. 15, 26, 34, with the area data in 1825 and 1900 reconstructed by the authors based on the information reported in refs. 17, 18, and 33. The data for Dongting Lake came from refs. 12, 19,23 , and $28-30$.

$\mathrm{y}^{-1}$ ) from peat mining, and swamp destruction accounted for $0.8 \%$ of $\mathrm{C}$ emission of China in 2000 (21).

\section{Biological Invasion}

The official statistics indicate that 127 alien invasive species have been detected in China, including 10 animals and 11 plants found in wetlands (27). The Environmental Protection Administration of China declared 16 notorious invasive species, including 5 wetlands species. These 16 species may cause 7.0 thousand million dollars (USD) of direct economic loss annually, much of which is attributed to the 5 species that invaded wetlands (24). For example, alligator weed (Alternanthera philoxeroides) was first recorded in the suburbs of Shanghai in 1892, and water hyacinth (Eichhornia crasssipes) was introduced into China in 1901 as a garden flower $(24,27)$. Native to South America, both species were used as forage from 1950 to 1980 , and currently occur in most lakes and rivers in eastern China (Fig. 4). Smooth cord grass (Spartina alterniflora), native to the Atlantic coast of North America, was introduced in 1979 to protect coastal dikes and to reduce coastal erosions from tides, and it is currently distributed in $1120 \mathrm{~km}^{2}$ of coastal areas. It was estimated that these three invasive species may have caused a total annual economic loss of 2.0 thousand million dollars (USD) $(2,22,27)$ in terms of jammed coastal waterways and economic species loss from habitat conversion and ecosystem collapses $(10,27)$.

\section{CAUSES OF THE WETLANDS PROBLEMS IN CHINA}

Numerous factors contributed to the loss and degradation of natural wetlands in China. The most important among them were land demands by a large population, a lack of understanding of wetland values, a misguided reclamation policy, a lack of environmental laws and regulations, and water diversion needed because of rapid economic growth. Here, we discuss three main causes for wetland loss over the years: reclamation, misguided policy, and water diversion.

\section{Reclamation}

Reclamation was the primary cause for wetland loss $(1,2)$. Reclamation of wetlands has a long history in China. For example, lakes along the midsections of the Yangtze River were firstly reclaimed about 2000 years ago (28), Jianghan-Dongting lakes in the middle Hanjing Dynasty (AD 25-380), and the Poyang Lake in the late Han Dynasty (BC 202 to AD 220). 


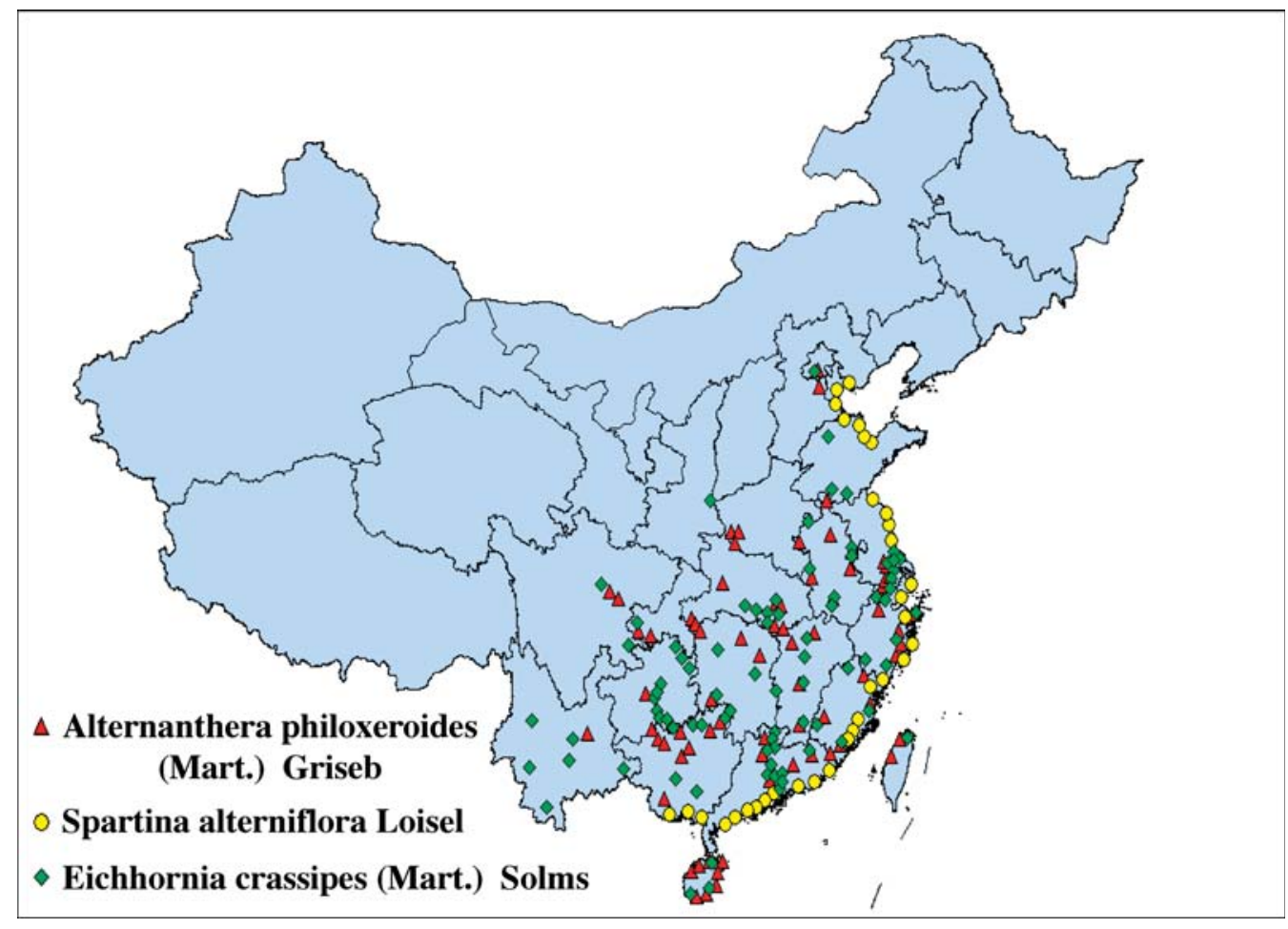

Figure 4. The distribution of three important invasive plant species in China's natural wetlands. The locations for the smooth cord grass are based on ref. 10, whereas the locations of both alligator weed and water hyacinth came from ref. 27, with minor corrections based on refs. 2 and 24.

Through history, additional waves of reclamation occurred during late Song (AD 1250-1276), Ming (AD 1470-1560), late Qing dynasties (AD 1780-1910), and the last century (mostly from 1950-2000) in the Dongting Lake, and during early Tang (AD 620-650), late Song (AD 1130-1270), late Qing dynasties (AD 1780-1910), and late last century (AD 1950-2000) in the Poyang Lake. The Dongting Lake, once the largest lake in China, shrank from the surface area of $18730 \mathrm{~km}^{2} 1500$ years ago to the current size of $2625 \mathrm{~km}^{2}$ (Fig. 3) (28-30). The lakes lost a total area of $13000 \mathrm{~km}^{2}$ to reclamation during the last 50 years alone, with most of the loss occurring along the Yangtze River (e.g., 41.0\% loss in Poyang Lake, 34.2\% loss in the lake group of Jianghan-Dongting) $(17,19)$. Other wetland types also suffered a great loss. Coastal wetlands in the Northern Jiangsu Province, the largest in China, were reclaimed since the late Han dynasty (BC 202 to AD 220). In addition, much of the 30000 $\mathrm{km}^{2}$ coastal lands generated during the last 4000 years by the sediment buildup near the mouths of major rivers in Jiangsu Province was reclaimed; only $900 \mathrm{~km}^{2}$ of these newly created wetlands remained undeveloped $(31,32)$. The largest swamps in China, the Sanjiang Plain, lost $83.7 \%$ of its total area during 1825-2000, with most of the reclamation taking place during the last 50 years (Fig. 3) $(15,33)$. It was estimated that a total of 133 $500 \mathrm{~km}^{2}$ of croplands, fishponds, salt ponds, and residential lands was obtained from the conversion of coastal wetlands in China (32). Overall, reclamation alone may account for $82 \%$ of the total wetland loss in China.

\section{Misguided Policy}

The accelerated loss of lakes, coastal wetlands, and swamps because of reclamation in the last 50 years (Fig. 3) was primarily the outcome of the reclamation policy by the Chinese government in that period $(5,10,33,34)$. As a country of agriculture, China has more people but less arable lands (122 million hectares) than the United States (638.8 million hectares) $(35,36)$. It was always (and still is) a struggle to produce enough grain for the population. As mentioned above, land reclamation had been regarded as a key solution, either from mountains (e.g., rice terraces) or from lakes and swamps. Thus, the strive for food security was the force that drove the reclamation policy of the Chinese government, and the large-scale reclamation during the last 50 years was sponsored by the government because building networks of levees and ditches required the kind of financial support and manpower that only governments could provide. However, recent natural disasters (e.g., the Yellow River dried up in 1997, the Yangtze River floods of 1998, Beijing's sandstorms of 2000s) brought the attention of the government and the public to the severe environmental problems caused by the policy of economic growth at all cost. The realization of environmental consequences of misguided policies also led to a change of attitude toward the environment in general and wetlands in particular $(1,2,5)$. As a result, it is safe to say that large-scale reclamation will not be allowed, even though the coastal wetlands and natural swamps are still under threat, because many local governments continue to consider them as potential land resources.

\section{Water Diversion}

Decreased water recharge was another key cause for natural wetland loss in China $(1,10,30)$. Water diversion to agricultural and industrial uses greatly reduced water flow into wetlands over the last 50 years. The area of the irrigated croplands increased by $340 \%$ from 1950 to 2000 (Fig. 2), and much of the water was lost because of low water use efficiency of irrigation $(15 \%-35 \%)(12,25,35)$. The excessive use of water by agriculture and other industries resulted in the extremely low river flow in the lower sections of many rivers (e.g., Yellow, Talimu, Heihe); for example, a stretch of the lower Yellow River (704 km) had no water flow for 226 days in 1997 (12, 37). Meanwhile, more than 120000 dams were constructed, with 46000 dams and 7000 water gates along the Yangtze River alone (including the Three Gorges Dam, the biggest dam in the world) $(12,23)$. These dams and water gates not only isolated $70 \%$ of the natural lakes from rivers but also interrupted the migration routes of aquatic species and drastically changed the fauna of lakes $(38,39)$. In western China, lake areas are encroached by the desertification process caused by droughts and the loss of vegetation cover $(1,9,17,18)$. The lakes of 
Manasi, Luobupo, Juyanhai, and many others dried up and became desert in northwest China, and the water levels in the lakes on the Tibetan Plateau decreased by $1.0-1.5 \mathrm{~m}$, primarily because of global warming $(17,18)$. Qinghai Lake, the biggest lake on the plateau $\left(4305 \mathrm{~km}^{2}\right)$, decreased by $17.2 \mathrm{~cm} \mathrm{y}^{-1}$ in water level and by $8.4 \mathrm{~km}^{2} \mathrm{y}^{-1}$ in area during 1908-1956 and by $10.8 \mathrm{~cm} \mathrm{y}^{-1}$ and $9.7 \mathrm{~km}^{2} \mathrm{y}^{-1}$ during 1957-1988, whereas the desert area around the lake increased to $1670 \mathrm{~km}^{2}$ from $450 \mathrm{~km}^{2}$ during the past 50 years $(17,18)$.

\section{CURRENT EFFORTS TO PROTECT THE WETLANDS}

The severe environmental problems associated with wetlands loss were recognized by the Chinese government in early 1970 s $(5,10)$, even though it did not appreciate the importance of the full range of ecosystem services provided by wetlands until recently $(2,10)$. The government passed the first environmental law in 1972 (10) and started taking a series of actions to remedy the problems $(5,18)$, including establishment of natural reserves, wetland restoration, water pollution control, fish population conservation, newly originated wetland protection, and invasive species management. These actions have shown promising results in reversing the trends of wetland loss and degradation (2). In China, natural wetlands are protected under a three-class system: the wetland reserves (i.e., full protection from development and most human activities), the wetland parks (i.e., full protection from development but use for ecotourism), and the scenic parks (i.e., protection from development but open to the public for recreation). We highlight some of these important actions taken or to be taken by the government in protecting, restoring, and creating wetlands in China.

\section{Wetland Reserves}

A wetland reserve is composed of a core area, in which human activities are prohibited, and a buffer zone, in which some human activities may be allowed upon approval. The Chinese government started to establish natural reserves of wetlands in the early 1970s. By 1980, 14 wetlands reserves, with a total of $5970 \mathrm{~km}^{2}$, were under protection $(2,24)$. By 2003, 477 reserves were established to protect wetlands and rare and endangered aquatic animals and plants (Fig. 5), including 69 managed by the national government, 166 by the provincial governments, and 242 by the local governments; the total conservation area has reached $425000 \mathrm{~km}^{2}$, including $145000 \mathrm{~km}^{2}$ of wetlands, $280000 \mathrm{~km}^{2}$ of marine and terrestrial ecosystems adjacent to the wetlands (2). In addition, the government plans to establish 225 new wetland reserves by 2010 and another 135 by 2030 when about $90 \%$ of natural wetlands in China will be under the protected status (2).

\section{Wetland Restoration}

China began restoring degraded wetlands in the early 1990s. To date, it has funded more than 200 pilot programs with 20.7 thousand million dollars (USD) to protect and restore existing natural wetlands, to create wetlands that have been lost, and to address other wetland-related issues $(2,5)$. During 2000-2005, a total of 36 projects were funded by the " 863 " environmental action plan, including 25 to restore water quality of natural lakes and rivers, and 11 to restore pollution purification capacity of urban wetlands (24). Funding has also been planned for at least 100 thousand million dollars (USD) to start another 53 large programs by 2030 that will restore and recreate additional $14000 \mathrm{~km}^{2}$ of natural wetlands $(1,2,5)$. The new policy to return some of the reclaimed croplands to the original wetlands or lakes is in effect $(2,23)$. According to the National

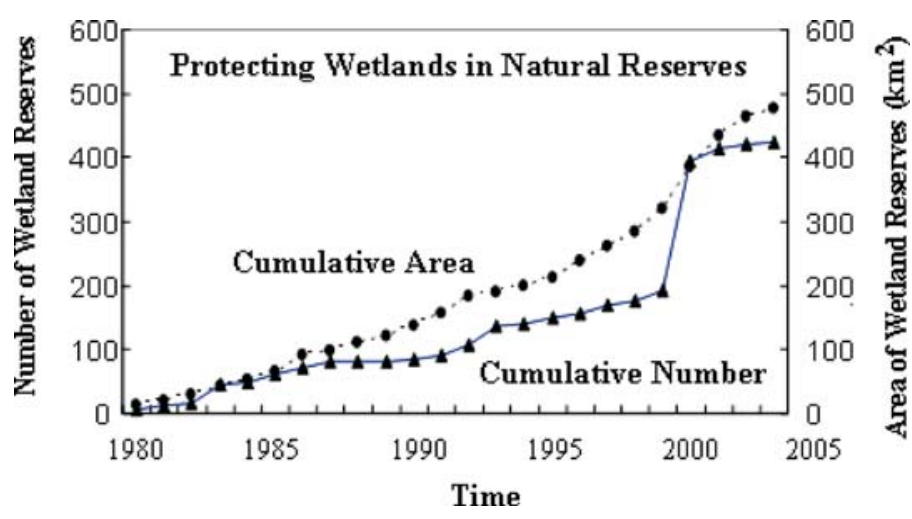

Figure 5. Wetland protection efforts as depicted by the increase in the number and area of natural reserves in China. The data came from refs. 2,5 , and 17.

Program of Wetland Protection Engineering issued in 2003, the Chinese government will allocate 112.5 million dollars (USD) during 2006-2010 to restore the degraded wetlands and to establish wetland parks and wetland reserves (2). For example, the government of Jiangsu province has started working on many projects, including restoration of Taihu Lake, Hongze Lake, and swamps along the Yangtze River; establishment of wetland parks at Qinghu Lake, Yangcheng Lake and Qinghuai River; and establishment of wetland reserves of the Big Canal, Hongze Lake, and Taihu Lake.

\section{Water Pollution Control}

A wastewater control action plan (24) was implemented to improve water quality and to protect the wetlands in the late 1990s, specifically to treat the heavily polluted rivers of Huaihe, Haihe, and Liaohe; the lakes of Chaohu, Taihu, and Dianchi; and the coast of the Bohai Sea. The action plan focused on point and nonpoint source pollution control, wastewater purification, and water resource and discharge management, and was composed of 2420 projects, with the total funding of 23.5 thousand million dollars (USD) in the last five years. The plan called for, but has not fulfilled, a reduction of chemical oxygen demand by $5.0 \mathrm{Tg}$, including $50 \%$ from domestic wastewater, $40 \%$ from industrial wastewater, and 10\% from rural areas by the year 2005. In addition, numerous laws and regulations about water quality have been enacted by the national, provincial, and local governments.

\section{Fish Population Conservation}

The regulation to prohibit fish harvesting in reproductive periods was implemented in Poyang Lake and Taihu Lake in 1986, in Dongting Lake in 1995, and in the Yangtze River estuary and marine fishing grounds in 2002 (40-43). The action plan to restock wetlands with fingerlings from hatcheries was started in 1999, and 245 thousand million individuals, including both commercial and endangered fish species, had been released into lakes, rivers and marine wetlands by 2005 (40-43). In addition, the World Wildlife Fund (WWF)-China funded projects that were to reconstruct free migration channels among four selected lakes (Zhangdu Lake, Hong Lake, and Tian'e Lake in Hubei Province, and Baidang Lake in Anhui Province) and the Yangtze River (23).

\section{Protection of Newly Originated Wetlands}

Protection of newly created wetlands is one of the national wetland action plans in China $(2,5)$. The runoff of $1570 \mathrm{~km}^{3} \mathrm{y}^{-1}$ into the sea $(59.0 \%$ from the Yangtze River) carries 15.3 
thousand million tonne of sediments into the estuaries each year, including 6.4 thousand million tonne from the Yellow River, 5.2 thousand million tonne from the Yangtze River, 1.6 thousand million tonne from the Haihe River, and 0.9 thousand million tonne from the Pearl River $(12,44,45)$. From the sediments, 10000 to $15000 \mathrm{~km}^{2}$ of new wetlands may originate in the estuaries of major rivers and nearby coasts in the next 50 years $(31,32,37,46)$. It is also estimated that over $100000 \mathrm{~km}^{2}$ of submerged alluvial deposits off the coast of the Yellow Sea may become terrestrial lands within 50-100 years if the current sedimentation rate remains unchanged (45). In addition, at the completion in 2008, the Three Gorges Dam will create a giant artificial lake of $1150 \mathrm{~km}^{2}$ of surface area, with additional 460 $\mathrm{km}^{2}$ of permanent wetlands and $4900 \mathrm{~km}^{2}$ of transient wetlands near the lake shores because of high soil moisture $(12,23)$. The South-to-North Water Diversion project is also expected to contribute to the fresh wetland generation in Northern China $(2,21)$. The National Program of Wetland Protection Engineering calls for protection of the newly created wetlands by establishing natural reserves and wetland parks (2).

\section{FUTURE CHALLENGES FOR CHINA'S WETLANDS}

Despite all that has been done, many challenges remain in terms of wetland policy, management, and science. First, success in wetland conservation requires science-based policies and effective laws and regulations. China still needs a specific law for wetland protection, which is in a slow process of being established. Current laws and regulations can be effective in stopping wetland loss and water pollution at large scales, i.e., protecting wetlands from reclamation and point-source pollution. However, cleaning up of water pollution will take a long time, and the water-resource shortage will remain a problem for years to come. Therefore, it will be a major challenge to the Chinese government to maintain a consistent policy on and a long-term commitment to wetland conservation and waterquality control. In addition, a system for monitoring and assessing at the national scale will need to be developed to ensure the effectiveness of the implementation of the policies, laws, and regulations, and the accountability of the funded programs. Second, effective implementation of the national wetland action plan requires a concerted efforts at all levels. The policies, laws, and regulations may fail to produce the expected outcomes unless new ideas and incentives are developed to provide local people with alternative ways of livelihood that will not cause disturbances to wetlands. It will be a challenge to find a balance between protection of wetlands and revitalization of the local economy in wetland regions. Significant obstacles to wetland preservation, such as local bureaucracy, lack of trained managers, misuse of wetland funding, and lack of appreciation of the ecosystem management principle, will also need to be removed. Educational campaigns to increase public awareness about wetland-related issues just started, but it will take a long time to change peoples' attitudes. Third, science is needed to provide the information for decision making and for training wetland professionals to manage natural reserves and wetland parks, and to educate local people. China lacks the scientific expertise and technical know-how in wetland restoration and in water pollution control and clean-up. Efforts to enhance scientific exchanges and communications will be needed to narrow the gaps and to generate scientific advancements to solve many of the problems. Another major challenge is the lack of graduate programs for wetland sciences in universities, which is the main reason for the lack of trained researchers and managers. There are only a few such wetland graduate programs in China.

Sustainable development in China requires new attitudes, sound policies, and great efforts in protecting natural wetlands and preserving their valuable ecosystem services. The natural wetlands in China are still under great threats by the large population and rapid economic growth. In fact, the economic miracle of China in the last 20 years came at the huge expense of the environment, especially the natural wetlands $(1,21)$. To reverse the trends, China faces enormous challenges. However, significant actions are being taken, including the plan designed to place $90 \%$ of the natural wetlands under protection by 2030 , the policy to return reclaimed croplands to wetlands (swamps, lakes), and the funding allocated to restore natural wetlands (2, $5,17)$. These actions will ensure that natural wetlands are protected and damages to wetlands in the past are repaired so that the country receives the full benefits of the ecosystem services provided by wetlands in the years to come. The future of China's wetlands looks promising, because China understands that protecting wetland ecosystems is a national imperative to guarantee a sustainable development of the economy of the country.

\section{References and Notes}

1. Li, K. and Zhang, M. 2005. The resource and conservation suggestion of wetlands in

China. Wetland Sci, 3, 81-86 (In Chinese).
State Forestry Administration of China. 2005. Wildlife and Wetland Reserves State Forestry Administration of China. 2005. Wildlife
Information. (http://www.cnwm.org.cn/wildlife/index.asp)

Chen, Z. and Zhang, X. 2000. The value of the ecosystem services of China. Chin. Sci. Bull. $45,17-22$.

. Costanza, R., d'Arge, R., de Groot, R., Farber, S., Grasso, M., Hannon, B., Limbueg, K., Naeem, S., et al. 1997. The value of the world's ecosystem services and natural capital. Nature 387, 253-259.

State Forestry Administration of China. 2000. China's National Wetland Conservation: Action Plan. China Forestry Publishing House, Beijing, 118 pp. (in Chinese).

6. Ramsar Convention on Wetlands. 2006. Classification System for Wetland Type. (http:/ www.ramsar.org/ris/key_ris.htm\#type)

Compiling Committee of Geography of China. 1985. Natural Geography of China. Science Press, Beijing, pp. 250-395 (In Chinese)

8. Zhao, J. 1995. Natural Geography of China. 3rd, Higher Education Press, Beijing, p. 58 (In Chinese).

. Lang, H., Lin, P. and Lu, J. 1998. Conservation and Research of Wetlands in China. East China Normal University Press, Shanghai, 420 pp. (In Chinese).

10. An, S. 2003. Ecological Engineering of Wetlands. Chemical Industry Press, Beijing, 528 pp. (In Chinese).

. Zhao, D. 1999. Coastal Vegetation of China. Ocean Press, Beijing, 297 pp. (In Chinese) Ministry of Water Resource of China. 2000. Report on Freshwater Resource of China. (http://www.mwr.gov.cn/)

Jin, X. 2001. Control and Management of Eutrophic Lakes. Chemical Industry Press, Beijing, 224 pp. (In Chinese).

4iao, D., Hu, Y. and Li, X. 2001. Landscape Ecology of Wetlands along the Coast of Bohai Sea. Science Press, Beijing, 417 pp. (In Chinese)

5. Zhao, K. 1999. Swamps of China. Science Press, Beijing, 718 pp. (In Chinese)

16. China's Soil Dataset. 2005. Swamp Soil Properties. (http://www.soil.csdb.cn/) (In Chinese).

17. Chen, Y. 1995. Studies of Wetlands in China. Jili Science and Technology Press, Changchun, $385 \mathrm{pp}$. (In Chinese).

18. State Forestry Administration of China. 1996. Protection and Wise Uses of Wetlands. China Forestry Publishing House, Beijing, 460 pp. (In Chinese).

1. China's Lake Dataset. 2005. Regional Data. (http://www.lake.csdb.cn/index-chn.asp) (In Chinese).

20. An, S., Wang, Z., Zhou, C., Guan, B., Deng, Z., Zhi, Y., Liu, Y. and Xu, C., et al. 2006. The headwater loss of the western plateau exacerbates China's long thirst. Ambio 35, $271-272$.

1. Liu, J. and Diamond, J. 2005. China's environment in a globalizing world. Nature 435, 1179-1186.

22. State Environmental Protection Administration of China 1998. National Report of Biodiversity of China. China Environmental Science Press, Beijing, 430 pp. (In Chinese) WWF China. 2005. Wetland Biodiversity and Services. (http://www.wwfchina.org/)

24. State Environmental Protection Administration of China. 2005. Environmental Report (http://www.zhb.gov.cn/)

25. National Bureau of Statistics of China. 2000. Agricultural Data. (http://www.stats.gov. cn/tjsj/qtsj/index.htm)

26. China's Swamp Dataset. 2005. Regional Sata. (http://www.marsh.csdb.cn/) (In Chinese).

27. Li, Z. and Xie, Y. 2002. Invasive Alien Species in China. China Forestry Publishing House, Beijing, 211 pp. (In Chinese).

. Dou, H. and Jiang, J. 2000. Dongting Lake. China Science and Technology University Press, Hefei, 344 pp. (In Chinese).

29. Zhao, S., Fang, J., Miao, S., Gu, B., Tao, S., Peng, C. and Tang, Z. 2005. The 7-decade degradation of a large freshwater lake in central Yangtze river, China. Environ. Sci. Technol. 39, 431-436.

30. Zhao, S. and Fang, J. 2004. Impact of impoldering and lake restoration on land-cover changes in Dongting Lake area, Central Yangtze. Ambio 33, 311-315.

31. Ren, M. 1986. Survey Report of Costal Jiangsu. Ocean Press, Beijing, 517 pp. (In Chinese).

32. Chen, J. 2000. To explore lower tidal flats for expending living spaces of China. Engr Sci. 2, 27-30.

Deng, W., Zhang, P and Zhang, B, 2004. Regional Development of Northeast Chine. Science Press, Beijing, 432 pp. (In Chinese)

34. Liu, H., Zhang, S., Li, Z., Lu, L. and Yang., Q 2004. Impacts on wetlands of large-scale land-use changes by agricultural development: the Small Sanjiang Plain, China. Ambio $33,306-310$

35. China's Scientific Dataset. 2005. Agricultural Data. (http://www.data.ac.cn/zrzy/ kulnew.asp) (In Chinese)

36. Liu, Y. 2006. Shrinking Arable Lands Jeopardizing China's Food security. (http://www worldwatch.org/features/chinawatch/stories/20060418-1) 
37. Shi, C. and Zhang, D. 2005. A sediment budget of the lower Yellow River, China, over the period from 1855 to 1968. Geografiska Annaler Series A-Physical Geography 87A, $461-471$

38. Xie, P. 2003. Three-Gorges Dam: risk to ancient fish. Science 302, 1149.

39. Park, Y., Chang, J., Lek, S., Cao, W. and Brosse, S. 2003. Conservation strategies for endemic fish species threatened by the Three Gorges Dam. Conserv. Biol. 17, 1748-1758.

40. China's Yearbook. 2000. Fishery Data. (http://www.yearbook.cn/link/yb.asp) (In Chinese).

41. Chinese Academy of Fishery Science. 2005. Fishery Data. (http://www.cafs.ac.cn/) (In Chinese).

42. China's Fishery Information Website. 2005. Fishery Data. (http://www.fish.net.cn/) (In Chinese).

43. State Ocean Administration of China. 2005. FisheryData. (http://www.soa.gov.cn/)
44. Hori, K., Saito, Y., Zhao, Q. and Wang, P. 2002. Architecture and evolution of the tidedominated Changjiang (Yangtze) River delta, China. Sediment. Geol. 146, 249-264.

45. Liu, X., Wang, K. and Zhang, G. 2004. Perspectives and policies: ecological industry substitutes in wetland restoration of the Middle Yangtze. Wetlands 24, 633-641.

46. Estuary and Coastal Information Website. 2005. Coastal Wetland Information. (http:/ www.cjk3d.net/index.php) (In Chinese).

47. Acknowledoments: We gratefully acknowledge the financial support from the projects of National Water Projects in Resoure and Environment Programs (2003AA06011000-4 Non Resch Projects (2002CB111504) and National Science Foundation of China (30400054). H. Li wishes to acknowledge that this pape has not been subjected to the policy review by USDA Forest Service and, therefore, does not necessarily reflect the views of the agency and no official endorsement should be inferred.

48. First submitted 25 September 2005. Accepted for publication 30 October 2006.
Dr. Shuqing An, the corresponding author, is a professor of wetland science at Nanjing University, and his research interests include wetland ecology, invasive species management and biogeochemical cycles. Addresses: The State Key Laboratory of Pollution Control and Resource Reuse, Nanjing University, Nanjing 210093, China; The Institute of Wetland Ecology and School of Life Science, Nanjing University, Nanjing 210093, China.

E-mail: anshq@nju.edu.cn

Dr. Harbin $\mathrm{Li}$ is a research ecologist with USDA Forest Service, and his research interests include wetland ecology and management, quantitative landscape ecology, ecological modeling, and ecosystem management with decision-support tools. Address: USDA Forest Service Southern Research Station, Center for Forested Wetlands Research, Charleston, SC 29414, USA.

E-mail: hli@fs.fed.us

Baohua Guan is a postdoctoral fellow. Address: The State Key Laboratory of Pollution Control and Resource Reuse, Nanjing University, Nanjing 210093, China; The Institute of Wetland Ecology and School of Life Science, Nanjing University, Nanjing 210093, China.

E-mail: bhguan@nju.edu.cn

Changfang Zhou is an associate professor with a PhD. Address: The Institute of Wetland Ecology and School of Life Sciences, Nanjing University, Nanjing 210093, China.

E-mail: zcfnju@ nju.edu.cn

Zhongsheng Wang is an associate professor with a PhD. Address: The Institute of Wetland Ecology and School of Life Sciences, Nanjing University, Nanjing 210093, China.

E-mail: wangzs@nju.edu.cn
Zifa Deng is a doctoral student. Address: The Institute of Wetland Ecology and School of Life Science, Nanjing University, Nanjing 210093, China.

E-mail: dengzf@nju.edu.cn

Yingbiao Zhi is an associate professor with a PhD. Address: The Institute of Wetland Ecology and School of Life Sciences, Nanjing University, Nanjing 210093, China.

E-mail: yingbiaozhi@nju.edu.cn

Yuhong Liu is a doctoral student. Address: The Institute of Wetland Ecology and School of Life Science, Nanjing University, Nanjing 210093, China.

E-mail: liuyuhong@nju.edu.cn

Chi $\mathrm{Xu}$ is a doctoral student. Address: The Institute of Wetland Ecology and School of Life Science, Nanjing University, Nanjing 210093, China.

E-mail: xuchi@nju.edu.cn

Shubo Fang is a doctoral student. Address: The Institute of Wetland Ecology and School of Life Science, Nanjing University, Nanjing 210093, China.

E-mail: shubofang@nju.edu.cn

Jinhui Jiang is a doctoral student. Address: The Institute of Wetland Ecology and School of Life Science, Nanjing University, Nanjing 210093, China.

E-mail: dg0230075@nju.edu.cn

Hongli $\mathrm{Li}$ is a doctoral student. Address: The Institute of Wetland Ecology and School of Life Science, Nanjing University, Nanjing 210093, China.

E-mail: honglili@nju.edu.cn 